\title{
Challenges of Integrated Water Resources Management in the Western Cape Province, South Africa
}

\author{
Ntokozo Malaza ${ }^{1}$, Azwihangwisi Irene Mabuda ${ }^{2}$ \\ ${ }^{1}$ Department of Environmental and Occupational Studies, Cape Peninsula University of Technology, Cape Town, South Africa \\ ${ }^{2}$ Department of Electrical, Electronic and Computer Engineering, Cape Peninsula University of Technology, Bellville, South Africa
}

Email address:

malazan@cput.ac.za (N. Malaza)

To cite this article:

Ntokozo Malaza, Azwihangwisi Irene Mabuda. Challenges of Integrated Water Resources Management in the Western Cape Province, South. Africa. Journal of Water Resources and Ocean Science. Vol. 8, No. 2, 2019, pp. 9-20. doi: 10.11648/j.wros.20190802.11

Received: September 3, 2018; Accepted: September 18, 2018; Published: June 5, 2019

\begin{abstract}
The increased demand for water and land in South Africa, in particular the Western Cape Province as a consequence of population growth, climate change and economic development has reportedly been accelerated from year to year. The province has been adhering to the Intergrated Water Resources Management (IWRM) which was developed in the Water Indaba of 2009 in order to respond to the joint National and Provincial action towards managing the water resources in the Western Cape Province. At the same time, there is growing empirical evidence that challenges the scientific consensus and the practical implications of implementing IWRM provincially and nationally, although the nature of the implementation challenges may differ in different contexts. Against this background, this paper investigates the nature of the practical challenges to implementing water resource management in the Western Cape region. The study reviewed existing literature on the various issues of IWRM in South Africa; the various basins in the country; the existing measures that the authorities have in place to deal with water resources management issues; the challenges that hinder the progress of their achievements and some suggestions that if considered can improve the current water resources management situations in South Africa. The availability of water and a broader range of water-related issues are identified. The recommended actions for improving the future IWRM are suggested. Challenges to improve the capacity buildings of IWRM related to enabling environment, institutional frameworks and management instruments are verified to contribute to the future directions for efficient problemsolving ability.
\end{abstract}

Keywords: Enabling Environment, Climate Change, Sustainable Development, Water Management Practices

\section{Introduction}

Globally, water resources are becoming increasingly vulnerable as a result of escalating demand arising from population growth, the need for increased food production, expanding industrialization due to rising living standards, pollution due to various anthropogenic activities, and climate change impacts. The traditional, single focus sectoral organisation of water management bodies has proved to be ineffective in dealing with the multifunctional nature of water. Many authors have described the situation as a crisis of governance. This led to the search for an appropriate management approach for water resources. In the process the concept of Integrated Water Resources Management (IWRM) has been developed by many theorists, policy makers and international bodies.

Consequently, ensuring availability and sustainable management of water has been adopted as part of the United Nations Sustainable Development Goals, Transforming Our World: the 2030 Agenda for Sustainable Development [23]. According to [17], even though who's definition of access to safe water which defines it as the receipt of 25-30 litres of safe water per person per day is acceptable, the notion of water scarcity has been a hot topic for many years as some perceive it as an issue of supply or demand or a merger of the two. According to [28], water services and access to water are also important features of water availability but are not constantly decided by scarcity. Sometimes, what generally is seen as water scarcity are policies promoted by the result of maladministration. At the same time, it is argued that the concept is poorly articulated by epistemic communities [6]. 
Yet, it is heavily marketed through professional communities, supported on the one hand, by the aid agencies and, on the other hand, by international declarations that adopt this concept [1].

Against this background, the objectives of this study are as follows: (1) to briefly overview the water availability and water-related issues in the province; (2) to evaluate the progress in implementing the IWRM plans in the Western Cape including the biases and problems being inherent inefficiency of national government and provincial administration; and (3) to describe the challenges and the benefits to the provinces applying it to their water resources management.

\section{Water Availability and the Seasonality of the Western Cape Climate}

South Africa is considered to be a water scarce country and, if the current rate of water usage continues, demand is likely to exceed supply at some point in the future. The improvement of water conservation, water quality and water use efficiency is a key national priority. When compared against a global rainfall average of $870 \mathrm{~mm}$ per year, the country only receives $450 \mathrm{~mm}$. This makes South Africa the world's 30th driest country [11].

Water in the Western Cape Province is a very scarce resource with an annual mean of rainfall which dropped from $544 \mathrm{~mm}$ in the period of $1944-1949$ to $348 \mathrm{~mm}$ in 2005 [15]. It also experiences with highest variability in its mean annual precipitation. For example, in June 2013 the Western Cape experienced extreme weather with very cold and heavy rains which lead to flooding in low lying areas, but in 2016 the province experienced very little rains. High levels of precipitation (over $2000 \mathrm{~mm}$ per annum) occur in the mountainous areas around the city (the Helderberg basin, Franschhoek and Steenbras) where the major dams are situated. Rainfall is seasonal, and mainly occurs during winter (MayAugust), while the period of October-March is the dry season.

The seasonal pattern and low level of rainfall makes the province highly dependent on stored water resources. Over 440 million $\mathrm{m} 3$ of wateris being stored in five major dams
(Wemmershoek, Steenbras, Voelvlei, Berg River and Theewaterskloof) in the surrounding catchments. Approximately 8 million $\mathrm{m} 3$ of bulk water supply currently comes from groundwater resources [11]. The construction of the Berg River projec near Franschhoek is the largest water infrastructure project in the Southern African Development Community (SADC). The dam was inaugurated in 2009, and yields an additional 80 million m3per annum increasing the water storage capacity of the city [11]. The province is facing various challenges with regard to water resources conservation and its management.

\section{Iwrm Paradigm in South Africa}

In dealing with the water crisis, management approaches and planning methods for water resources are mandatory in order to avoid environmental deterioration of water bodies (National Water Act, Act No. 36 of 1998). The debate on water management has involved the science community and the policy world. As the South African government is the custodian of all water bodies, this paradigm urges the government to involve various stakeholders for matters pertaining to water resource management to promote efficient water use and the protection and conservation of catchments/water resource bodies. The foundation of this thinking is to enforce sustainable development in water resource management initiatives which will be able to restore and maintain a continuous flow of water (National Water Act, Act No. 36 of 1998).

Many water theorists favour IWRM as the best way to manage water resources [13] and it now enjoys international endorsement at the highest level, such as the 2002 World Summit on Sustainable Development (WSSD), Johannesburg, and the different World Water Forums [14]. This global paradigm shift from single purpose/sector specific approaches to IWRM is good because it is comprehensive and holistic considering all sectors, all types of water and all resources in the region at the same time and 'reinforces an ecological approach to land use and planning' [19] (Table 1).

Table 1. Changing paradigms in water resources management in the Western Cape.

\begin{tabular}{|c|c|c|c|c|}
\hline & \multicolumn{4}{|c|}{ Old (1912-1997) and new (1998-present) paradigms and their implications in water resources management } \\
\hline & Old paradigm & Implication & New paradigm & Implication \\
\hline \multicolumn{5}{|l|}{ Elements } \\
\hline Government regime & apartheid & $\begin{array}{l}\text { system of segregation or } \\
\text { discrimination on grounds of race }\end{array}$ & Democracy & $\begin{array}{l}\text { All the eligible members } \\
\text { participate }\end{array}$ \\
\hline Administrative rule & Centralisation & $\begin{array}{l}\text { Concentration on national } \\
\text { administration }\end{array}$ & Decentralisation & Provincial administration \\
\hline $\begin{array}{l}\text { Decision making } \\
\text { process }\end{array}$ & Top down & $\begin{array}{l}\text { All decisions made based on } \\
\text { administrator interests }\end{array}$ & Bottom up & $\begin{array}{l}\text { All decision made based on } \\
\text { stakeholders aspiration }\end{array}$ \\
\hline Budgetary system & $\begin{array}{l}\text { Government } \\
\text { allocation }\end{array}$ & $\begin{array}{l}\text { Financial sources from government } \\
\text { budget }\end{array}$ & Water users sharing model & $\begin{array}{l}\text { Financial sources from water user, } \\
\text { polluters and government budget }\end{array}$ \\
\hline Project interests & $\begin{array}{l}\text { Supremacy } \\
\text { instruction }\end{array}$ & Increase in personal popularity & People aspiration & Solving water related problems \\
\hline Project preparations & $\begin{array}{l}\text { Based on short term } \\
\text { planning }\end{array}$ & Based on local/personal interests & Based on master plan & $\begin{array}{l}\text { Approved based on } \\
\text { comprehensive studies }\end{array}$ \\
\hline
\end{tabular}




\section{Water Related Challenges in the Western Cape Province}

\subsection{Climate Change}

Climate change increases the probability of extreme weather events such as droughts, gradual variations in temperature and rainfall. Warming of the earth witnessed in the past 5 decades is attributed to anthropological actions [28]. In the Western Cape, suggestions from climate change projections indicate increased variability in precipitation, regular extreme events and increased temperatures. The province is currently experiencing drought conditions which are characterised by very low rainfall. The province is extremely under pressure as the dam's levels are critically low because of severe prolonged drought. This is evident by researchers from the Alliance for Collaboration on Climate and Earth Systems Science (ACCESS) in collaboration with the South African Weather Service (SAWS), the Council for Scientific and Industrial research (CSIR), the University of Cape Town, the University of Pretoria, the World Wildlife Fund (WWF), the South African Environmental Observation
Network (SAEON), the Agricultural Research Council (ARC) and other organisations including local and provincial government. The researchers are in agreement that the extremely low reservoir levels are a result of an accumulated 2-3 years of relatively low winter rainfalls which limited the reservoir levels. They also argue that the current drought is a combination of a decrease in previous years' rainfall as well as an increased demand for water.

Climate change affects water quality i.e. creeks and groundwater become more saline. As the levels of the sea rises which results from the warming of the earth, an intrusion into groundwater tables and creeks in the coast occurs [22]. Another problem is that the recharge rate is decreased which results in the concentration of salts being increased. Furthermore, the presence of pollutants will be promoted and such sediments, dissolved organic carbon and pesticides will flourish due to warmer water temperatures which will lead to longer periods of low flow [22]. The amount and location of accessible usable water is affected byalterations in precipitation patterns, surface runoff, evaporation rates, groundwater recharge and water quality which are said to result from climate change [22].

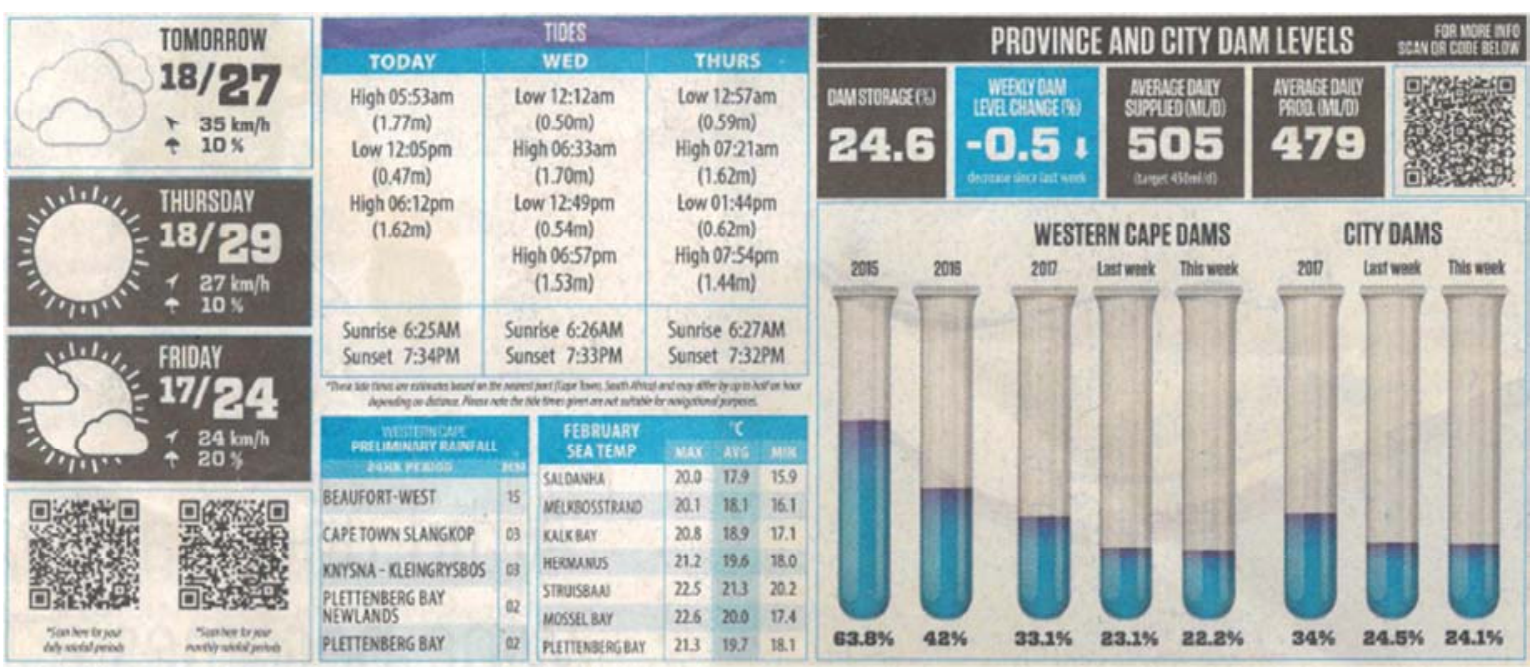

$20 / 02 / 2018$

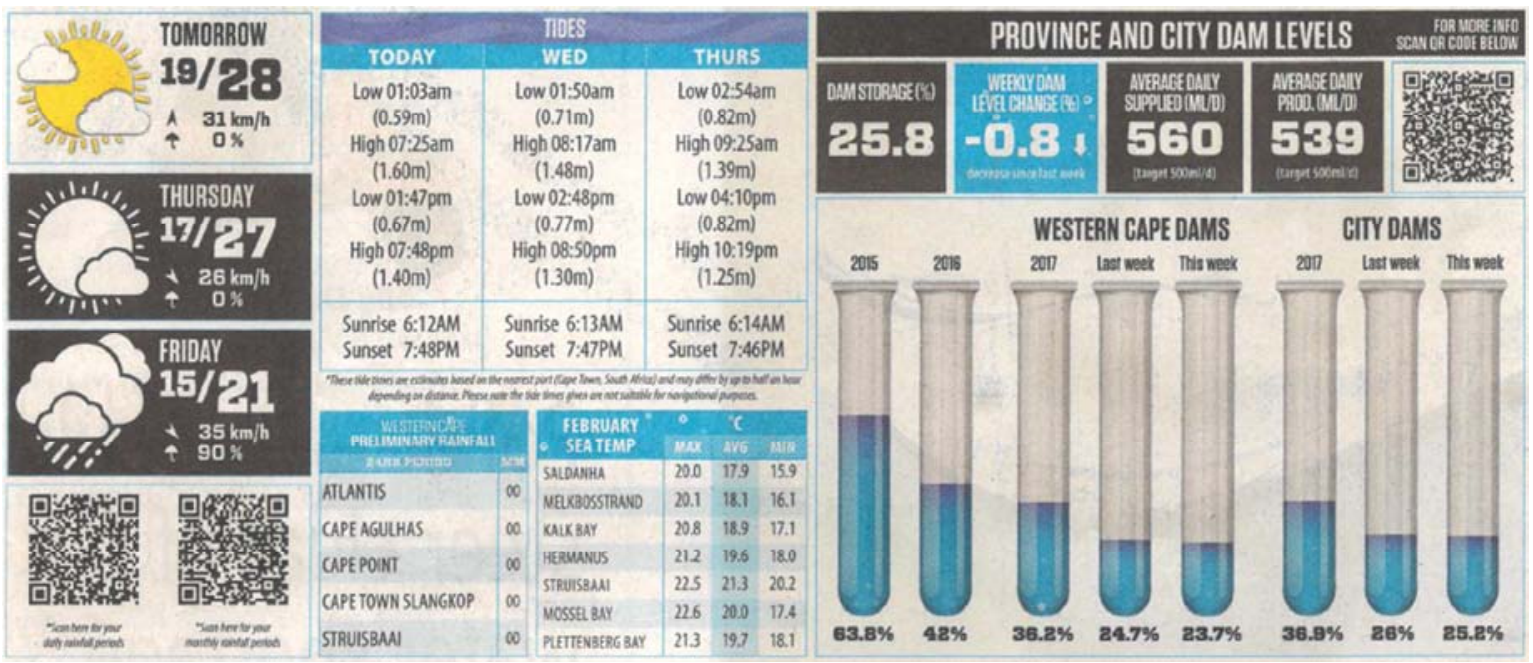

06/02/2018 


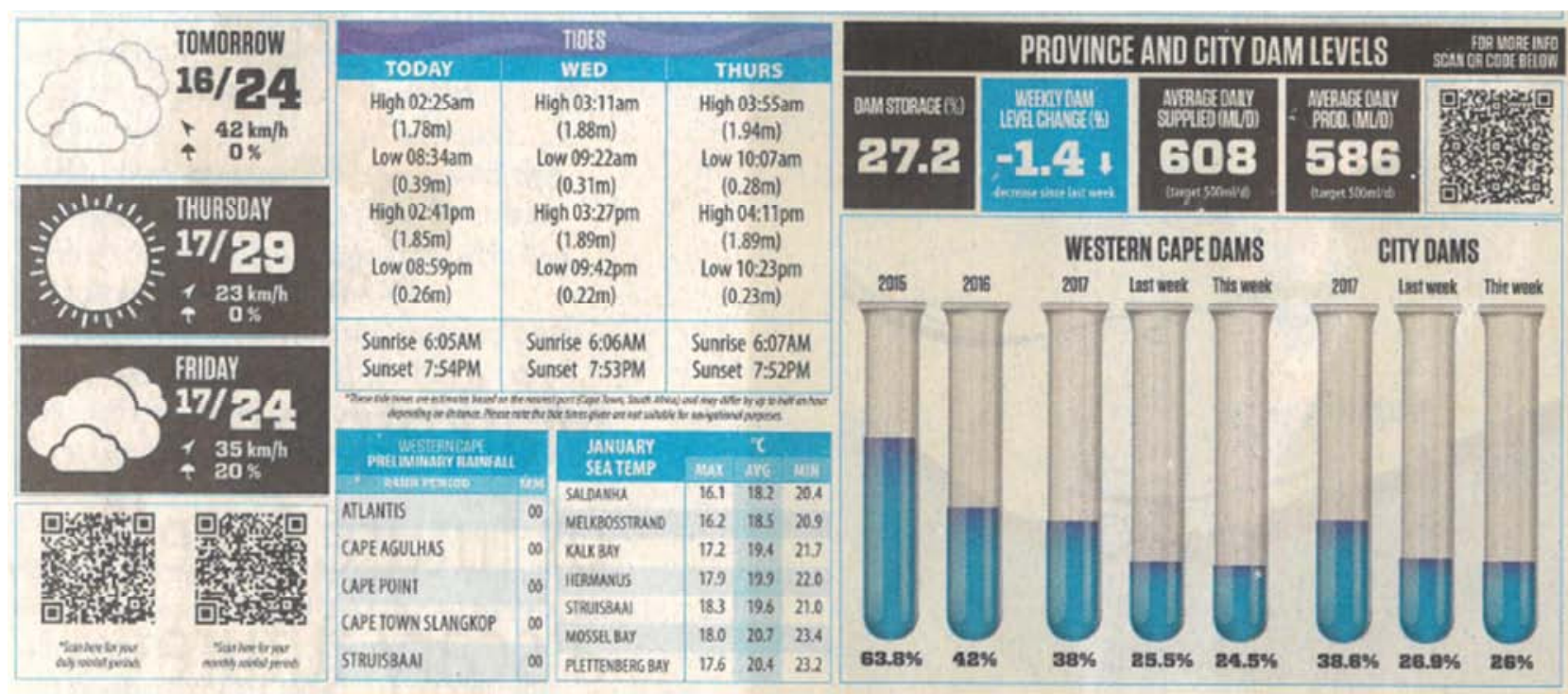

$30 / 01 / 2018$

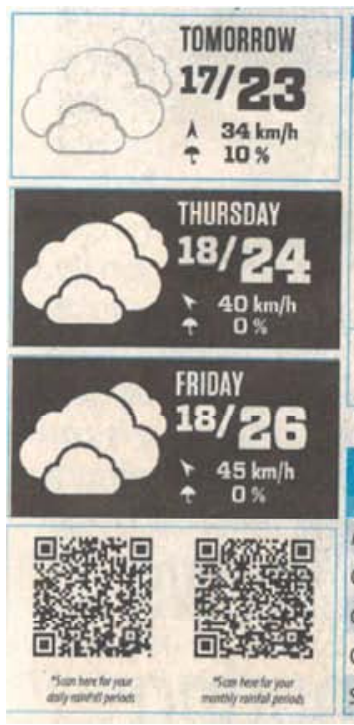

\begin{tabular}{|c|c|c|c|c|c|}
\hline & & Hots & & & \\
\hline TODAY & & WED & & IHURS & \\
\hline $\begin{array}{c}\text { Low 12:36am } \\
(0.57 \mathrm{~m})\end{array}$ & & $\begin{array}{l}\text { ow 01:25am } \\
(0.64 \mathrm{ml}\end{array}$ & & $\begin{array}{l}w 02: 312 \\
(071 \mathrm{~m})\end{array}$ & \\
\hline High 07:01am & & igh 07:54am & & th $09: 01$ & \\
\hline$(1.63 \mathrm{~m})$ & & $(1.58 \mathrm{~m})$ & & $(1.53 \mathrm{~m})$ & \\
\hline $\begin{array}{c}\text { Low 01:19pm } \\
(0.63 \mathrm{~m})\end{array}$ & & ow $022: 22 \mathrm{pm}$ & & $N 03: 42$ & \\
\hline $\begin{array}{l}\text { High 07:23pm } \\
\text { (1.45m) }\end{array}$ & & igh 08:27pm & & ho9:49 & \\
\hline Sunrise 5:58AM & & nrise 5:59AM & Sunri & ise 6.00 & \\
\hline Sunset 7:58PM & & nset 7:57PM & Suns: & Set 7.5 ? & \\
\hline 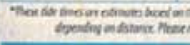 & ati & 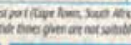 & neveres & cogyen: & tranes \\
\hline 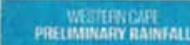 & & IANUARY & & $\tau$ & \\
\hline sumezostas & $\operatorname{mex}$ & SEA TEMP & 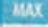 & AVG & sing \\
\hline ATLANTIS & $\infty$ & SALQNAH & 16.1 & 182 & 20.4 \\
\hline CAPEAGULHAS & & MEurbosstiquD & 16.2 & 18.5 & 20.9 \\
\hline CAPEAGULHAS & $\infty$ & MLKBAY & 172 & 19.4 & 21.7 \\
\hline CAPE PONT & $\infty$ & hearanus & 179 & 199 & 220 \\
\hline CAPE TOWN SLANGKOP & $\infty$ & STRUISEMAI & 18.3 & 19.6 & 21.0 \\
\hline SIRUISBAAI & & MOSSE Bar & 180 & 207 & 23,4 \\
\hline & $\infty$ & PLEIENBERG BAY & 17.6 & 20.4 & 23.2 \\
\hline
\end{tabular}

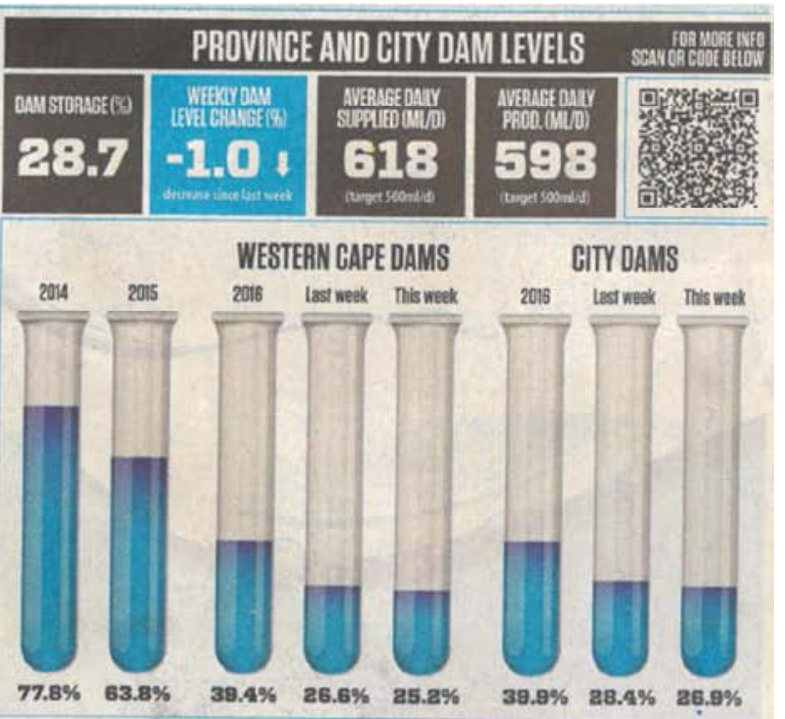

$23 / 01 / 2018$
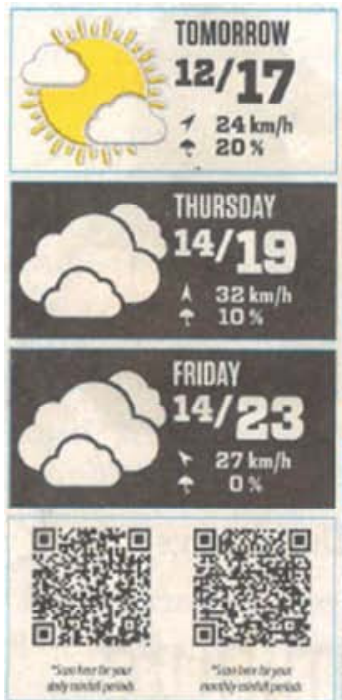
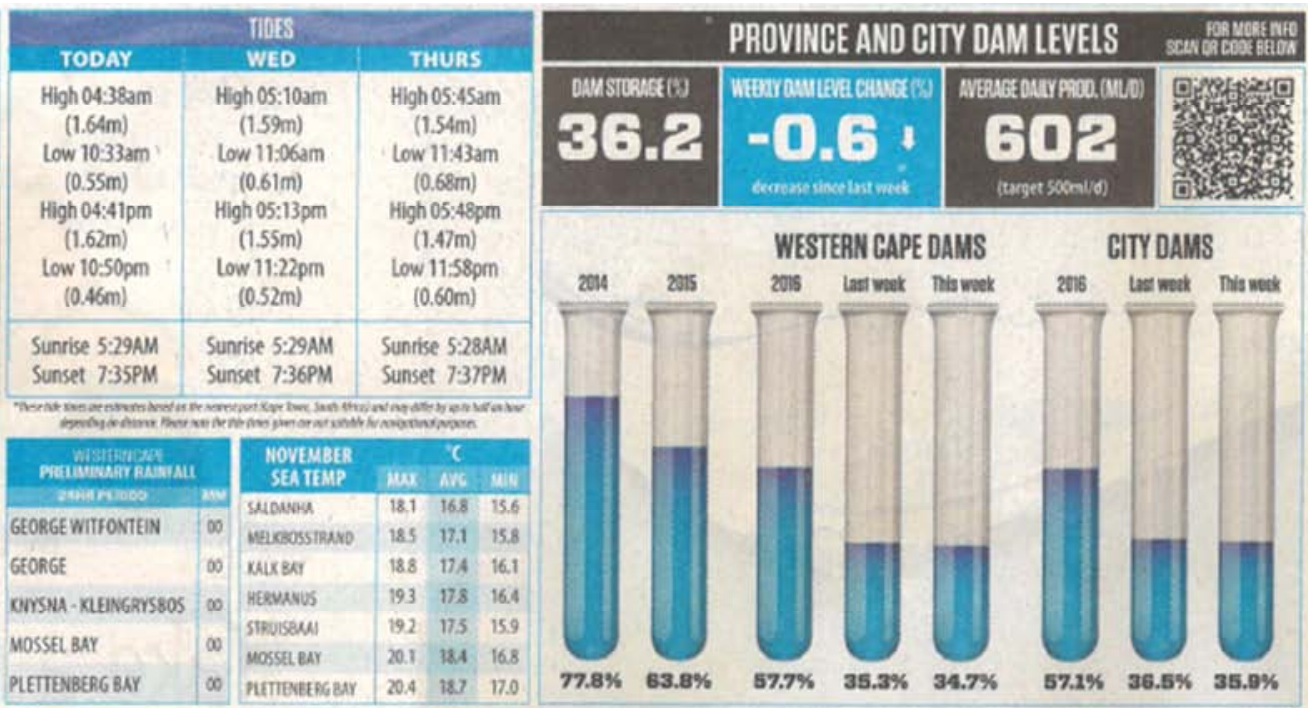


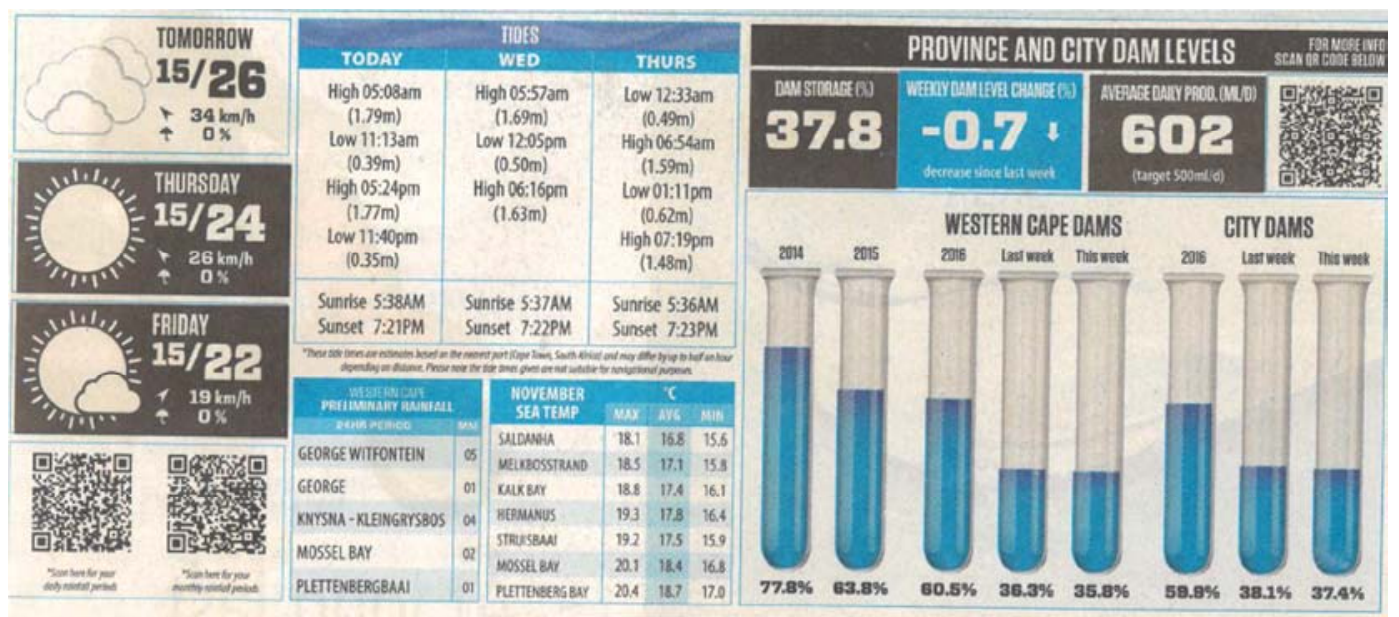

$07 / 11 / 2017$

Figure 1. Western Cape Province and the City of Cape Town dam levels and weather focus for selected Tuesdays in the month of November; (a) 20/02/2018 (b) 06/02/2018 (c) 30/01/2018 (d) 23/01/2018 (e) 21/11/2017 and (f) 07/11/2017 (Source: [2] and [3]).

In the province, climate change is projected to alter present hydrological resources and place added pressure on the adaptability of future water resources [16]. Most of South Africa has experienced extensive droughts in the past few decades, the most recent being in 2000 - 2001 and 2004 2005 [28]. The province dam levels have been recorded at their lowest during the summer months of 2017 and 2018 (Figures 1, 2 and 3). Droughts affect both surface and groundwater resources and can lead to reduced water supply. Furthermore, droughts interrupt the transportation of sediments, organic matter and nutrients to surface waters through runoff. Most researchers believe that the change of climate have resulted in very less water recharge to water resources and have caused water stress in the Western Cape Province at large.

\subsection{Population Growth, Poverty and Informal Settlements}

Exponential growth is synonymous with increasing demand and competition for water for domestic, industrial, and municipal uses thus population growth is a major contributor to water scarcity [29]. An increase in population in the province limits the amount of water available for everyone, with per capita water availability projected to fall by half in 2050. Most of the water used in the city is for agricultural purposes and a growth in population means more food is required. However, more water is required to ensure that food is available, therefore, the production of food is a significant part of food security thus food insecurity and water scarcity are interconnected. This is particularly concerning as there will be a need to increase production in the agricultural sector which will place further stress on water resources. Poverty and unemployment will cause people to migrate from rural areas to urban areas in search of work opportunities. However, this will cause people to become concentrated in one area leading to heavy burdens on water resources. Moreover, there will be an intensification of water demand and a strain on local water capacity due to increases in per capita water consumption driven by development. There is also a growing water demand for industrial use as rapid industrialization tries to meet the needs of a rising population. This will cause more stress on water resources as industrial production is heavily reliable on water for processing, cooling and disposal of waste products.

The province and the greater city of Cape Town face challengesin providing basic services in informal areas. Informal settlements are impoverished communities as they are unable to pay for water related services. Therefore, it is the duty of the government to provide water services in such communities. These settlements are marked by daily invasion of informal settlers, thus increasing the number of people who live in them and so is the amount of water needed.

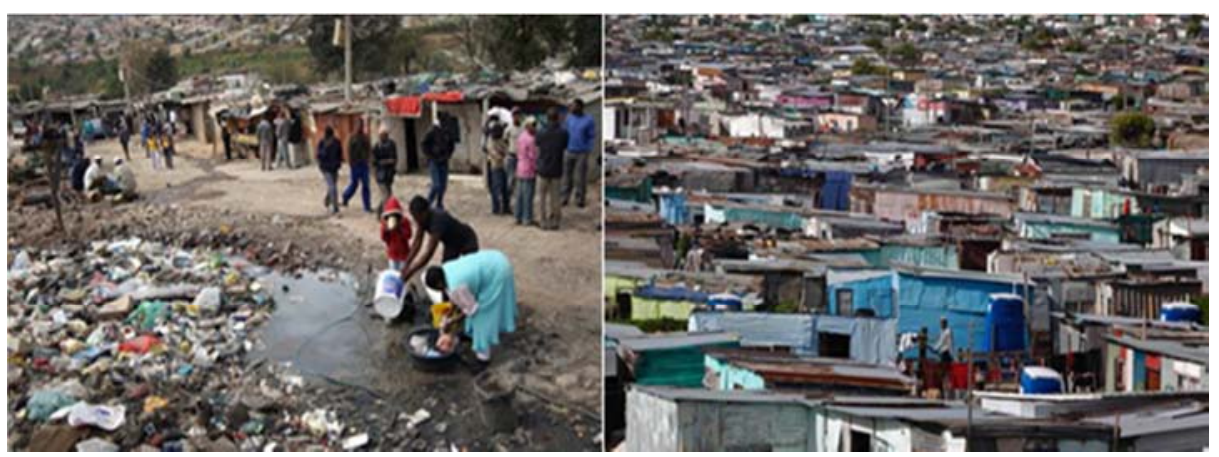

Figure 2. Informal settlements in Khayelitsha, an outskirt of Cape Town. 


\subsection{Water as a Resource for Agricultural Productivity}

The province is characterized by various agricultural activities. These activities include citrus farming, vineyards (grapes), potato farming, vegetable farming etc. The common attributes with these specific agricultural activities is that they require irrigation in order to produce their end products. The agricultural field is also a market driven commodity in that it plays a competitive role in the global market, contributes to the country's GDP and they also have influence in market prices of their products. The Department of Water Affairs maintained that irrigated agriculture is the largest single use of water in South Africa (accounting to $60 \%$ ) and it has a huge potential of socio-economic impact in rural communities. Water is the major limiting factor to the growth of this sector and poor water quality has a negative impact on agricultural exports and associated foreign income [10]. Moreover, there is large consumption of water resources in order to produce crops. With the growth in the country's population and the province's population as well, there is without doubt increasing food demand to cater for.

Therefore the agricultural industry poses an inconvenience in the aspect of water sharing needed for domestic use and/or for commercial purposes. This scenario is related to the assurance of having enough food available at all times. This is important because in order to have food security there needs to be enough water allocation to irrigated agricultural activities [9]. The agricultural sector is a water user and therefore it is the duty of the government sphere to manage and control utilization of water resources by the agricultural industry. There are a number of agricultural activities which are produced at certain periods of the year in the province which includes vineyards which is dependent on the winter rainfall. If the rainfall rates decrease and patterns changes, crops require other interventions, which in this case it is irrigation. Now, with the water being scarce in the province the use of dam water for irrigation has created water stress issues.

\subsection{Water Quality Issues}

The human population and the natural ecosystems elements are all dependent on clean water. The quality of water is compromised by a number of aspects that include the use of pesticides and fertilizers in the agricultural sphere, pollution of all kinds (air is attributed to emissions of greenhouse gases to the atmosphere by industries and transport systems of the world, land pollution cause by landfills and illegal disposal of waste which also causes ground water contamination, sedimentation from agricultural activities and water pollution in water bodies where the disposal site is in a tributary or near a water source).

The province of the Western Cape, and its Water Service Authorities, currently owns, operates and maintains 156 Wastewater Treatment Works (WWTWs). In the city of Cape Town there are 24 WWTWs, all of which need to be upgraded to meet the DWA's requirements (Western Cape
Government, 2012 (a)). A national survey on Wastewater Treatment in South Africa reported that a significant number of WWTWs are not properly operated and maintained and discharge poor quality effluent to streams and rivers. This situation is intolerable as it impacts directly on the downstream water users, the quality of natural waters and the cost and availability of potable water and its treatment in South Africa.

\subsection{Alien Invasive Species}

According to [4] alien invasions reduce the annual rainfall by $350 \mathrm{~mm}$ per annum in the catchments of the Western Cape and these catchments have an average annual rainfall of about $1500 \mathrm{~mm}$ of which around $600 \mathrm{~mm}$ reaches the streams. The displacement of natural vegetation by invasive species will intensify this use by $350 \mathrm{~mm}$ per annum leaving only $250 \mathrm{~mm}$ per annum for the streams (Chamier et al., 2012). Therefore, widespread alien invasion of mountains is likely to have a harmful impact on water supplies. The displacement of fynbos which is an indigenous species by pine trees resulted in stream flow reductions of up to $50 \%$ in the Western Cape [5]. Furthermore, groundwater-dependent alien plants present various challenges to an already waterscarce South Africa since they consume individually up to 50 litres of water per day [12]. These species access ground water using their deep tap roots which have been recorded at depths of about $50 \mathrm{~m}$ in some parts of the arid savannah [12]. Alien plant species may transpire for water four times more than indigenous plants. Moreover, invasive plants are very dense in comparison with indigenous vegetation and their ability to form dense thickets with large numbers of plants per unit area as opposed to high transpiration by singular trees is the central reason why they use more water than indigenous plants [4].

\subsection{Water Governance and Management Practices}

The Department of Water Affairs is the custodian of all water affairs in the country working with the department of environmental affairs and development planning, local government and agriculture. The Department has developed various plans with regard to water resources management and in particular to Western Cape and these are; Western Cape Sustainable Water Management Plan of 2012, Western Cape Integrated Water Resources Management Action Plan of 2011. The IWRM plans are well developed with clear objectives and recommended institutional structures that can effectively carry out these tasks. The major shortfall with these plans is lack of implementation which is fuelled mostly by financial constraints and political interventions. Lack of leadership continuity, shortage of skills and high staff turnover are other contributing factors hindering progress in terms of implementation of these plans (Integrated Water Resources Management Action Plan, 2011). The effective implementation of IWRM due to its complexity can be best done in an iterative, 'learning-by-doing' approach which is 
reflexive in nature and builds learning into the next management cycle [20].

\section{Iwrm Implementation in the Western Cape}

\subsection{The Development and Acceptance of Iwrm in South African Provinces}

South Africa's national water policies and legislation fully subscribe to protecting and managing the natural resource base of economic and social development as stated in the National Water Act of 1998 [8]. A report by the Water Resource Commission (WRC) unearthed all water court cases since 1912 to 1998 [24]. Under the 1998 Act, a complete record of all water cases was required, to determine existing lawful water uses for purposes of the establishment of water use entitlements under the new acts, and also to understand the water law of the previous dispensation, to facilitate continuity of water use and water resource development and management [24]. The author found that the majority of water court cases were decided before 1956, when water users relied heavily on the courts to establish and declare their water rights, mainly because the water law was a statutory system and not an administrative system. After the 1956 Act, the minister increased the asssumption of control over water sources, by the declaration of government water control areas [24].

\subsubsection{Water Laws}

In pre-colonial times, comprehensive customary local approaches with taboos and prohibitions backed by authorising systems played a key role in water laws [1]. Customary laws and practices covered water conservation, pollution control, protection of catchments and protection of fisheries [1]. In South Africa, water laws were first established in 1652 during the arrival and establishment of the Dutch Colony at the Cape of Good Hope, present day the province of the Western Cape [21]. In 1655, Jan Van Riebeeck established the first act of State (by way of Placcaet) control over public streams to prohibit upstream use of streams for washing persons and possessions [21]. Water courts were established by colonial legislation, consolidated in the Irrigation Act, 1912, and abolished by the National Water Act, 1998 [24].

\subsubsection{Water Legislation}

Prior to colonisation of South Africa, African customary law governed water rights in the pre-colonial society [21]. The Bantu people of Southern Africa had a subsistence economy based on hunting of animals and gathering of food. The San were hunter-gatherers while the Khoikhoi were stock farmers. In these native communities water like land was free, but land tenure was controlled by the chief and private ownership was not permitted [21]. There are two general water Acts which were current during the period of 1912 to 1998, namely the Irrigation and Conservation of Waters Act 1912 (Act 8 of 1912), and the Water Act 1956 (Act 54 of 1956). The 1956 Act repealed the 1912 Act and the 1956 Act was inturn repealed by the National Water Act 1998 (Act 36 of 1998) [24]. Table 2 summarises the South African water related laws from 1912-1998.

Table 2. South African water related laws enacted (1912-1998) [21].

\begin{tabular}{ll}
\hline Year & Water laws \\
\hline 1912 & $\begin{array}{l}\text { Completion of the codification of the law of water rights for the Union of South Africa. } \\
\text { A Commission of Inquiry into Water Matters was set up to report on the water needs of various secondary water users as well as their } \\
\text { effects on water availability. The Commission of Inquiry was set up with pressure from the lobbying of the industrialists who had the } \\
\text { support of mining and commerce industries. The report of this Commission became the basis for the new Water Act (No. 54 of 1956). This } \\
\text { permitted the state to use the principle of government control areas which was systematically extended to cover in some or other measure } \\
\text { all sources of natural water. The state was thus re-invested with dominus fluminis status for all practical purposes, bearing in mind the } \\
\text { increasing demand for water and fixed water supply. }\end{array}$ \\
& $\begin{array}{l}\text { Water rights for the forestry sector controlled by an Act of Parliament after its identification as a major water user with direct effect for } \\
\text { downstream users. }\end{array}$ \\
& $\begin{array}{l}\text { The democratic transition necessitated a water legislation rationalisation and amendment process. Consultations that led to the writing of a } \\
\text { new Water Act began. }\end{array}$ \\
1994 & The Fundamental Principles and Objectives for a New Water Law in South Africa were approved by the Cabinet. \\
1996 & The National Water Act and Water Services Act were passed and published.
\end{tabular}

\subsubsection{The Recent Policies and Practice of Iwrm in the Western Cape Province}

Because the implementation of IWRM in the Western Cape and South Africa in general remains theoretical, some limitations play out in practice, such that: (1) regulatory functions and service provision functions of water resources may still amalgamate; (2) law enforcement is not fully functional as well the frameworks for water management have not yet been legalized; (3) most human resources in the water resources sector, especially those in the fields and offices are not trained professionally for their respective jobs;
(4) there is still lack of enough participation by both the Departments of Basic and Higher Education and Training in executing IWRM education; (5) municipal infrastructure are not adequately operated, maintained and refurbished due to lack of public participation, resources and capacity; (6) Focus on politics of responsible people in the water resources sector instead of good governace with regard to IWRM.

The Department of Water Affairs and Sanitation (DWAS) is the government department responsible for the formulation and implementation of policies governing South Africa's water and sanitary sector. It strives to ensure that South 
Africans gain access to clean water and safe sanitation, and promotes effective and efficient water resources management to ensure sustainable economic and social development [8]. Presently it is responsible for water resource management in terms of developing policies, implementing programmes as well as monitoring and regulating all South Africa's water resources.

\subsubsection{The Iwrm Action Plan for the Western Cape Province 2009}

At the Water INDABA, Western Cape, held in November 2009, the Provincial Department of Environmental Affairs (DEA) and Development Planning (DP), in conjunction with the National Department of Water Affairs, other Provincial Departments and Local Government in the Western Cape agreed to develop an Integrated Water Resource Management (IWRM) Action Plan for the Western Cape Province. The plan was set up to identify short, medium and long term actions to guide implementation of projects/activities towards achieving integrated water resource management in the Western Cape.

The development of the IWRM Action Plan was separated into two phases, the first being the Status Quo Phase I, and the second being the IWRM Action Plan Phase II [25]. Each Phase of the project was planned to incorporate public engagement sessions at various representative areas within the province. The objective of this Phase is to determine the current status of water resources in terms of water quality, water supply and demand, and water and land use practices [26]. The Status Quo Report has investigated:

(a) Gaps and overlaps in Legislation (National, Provincial and Local Government Legislation);

(b) Gaps and overlaps in Institutional Structures;

(c) Review of Existing Strategies, Plans and Programmes;

(d) Review of Water Availability;

(e) Review of current Water Quality and Monitoring Programmes;

(f) Water and Climate Change;

(g) Water and Land-use / Planning;

(h) Summary of public engagement meetings and

(i) I dentified problem areas.

The objective of Phase II was to promote integrated water resource management that focuses on water quality and water quantity and demand management in the Western Cape. This phase investigated:

(a) Actions and activities, as in Status Quo Report;

(b) Performance measures/indicators linked to actions;

(c) Short, medium and long term timeframes for actions;

(d) Roles and responsibilities of Government and Stakeholders and

(e) Indicative costing of the actions.

\subsubsection{Western Cape Sustainable Water Management Plan 2011}

The Sustainable Water Management Plan (hereafter referred to as "the Water Plan") for the Western Cape Province was developed, following the recommendations made at the Water INDABA held in Cape Town during
November 2009. Its development was undertaken collaboratively by the Western Cape Government and the National Department of Water Affairs. Short (1-5 years), medium (6-15 years) and long term (+16 years) actions to guide the implementation of projects / activities were developed, as a means towards achieving integrated and sustainable management of water in the Western Cape [25]. The overall aim of the Water Plan was to guide sustainable water management towards meeting the growth and development needs of the region. According to the province, these practices were geared towards reducing the amount of water used and also to increase water provision in an efficient manner. The Water Plan covered four Water Management Areas (WMAs), namely; Olifants-Doorn, Berg, BreedeOverberg and Gouritz, and small section of the Fish to Tsitsikamma (Figure 3). The idea for this was to provide for sustainable water management in the province in which it aims at meeting its growth and development needs without jeopardizing ecological integrity [25]. The IWRM paradigm is concerned with the implementation of policies, plans and programs for development of national and/or regional strategies, plans and programs with regards to river basin, watershed and ground water management [10]

\subsubsection{Recent Water Plans Critical Water Shortages Disaster Plan}

In October 2017, the City of Cape Town came up with a new plan called the Critical Water Shortages Disaster Plan. The severe water shortages in the province called for different management practices to be adopted in dealing with the current drought crisis. According to the greater City of Cape Town's statement, the full plan comprised of three phases, and supported by sectoral operational plans and protocols, which guides the city's operations and preparedness actions in the unlikely event of critical water shortages. The disaster plan which entails water rationing as Phase 1; Phase 2 comprises disaster phases and Phase 3 comprises a more extreme disaster interventions.

Phase 1: Preservation Restrictions - rationing

Implementation of this phase included instituting water rationing through limiting supply and advanced pressure management. Limiting supply entails the controlled manual closing of valves to reticulation sub-districts in the city to further drive down demand. Advanced pressure management entails the limitation of water into the water reticulation system through automatic controllers at specific choke points.

This process did not result in a complete shutdown of the water reticulation system, but it severely limit available water supply in the system per day, some areas experienced water supply outages. During such time, short periods of limited to no water available to some neighbourhoods. Water users were advised to make alternative arrangements for water or store water for usage. It was advised that up to five litres of water was to be kept as emergency storage for essential usage in the event of intermittent supply. Numerous gaps, concerns and issues were identified during Phase 1. These themes are: 
Institutional Capacity, Cooperative Governance, Enforcement and Legislation, Water Conservation/ Water Demand Management, Ecological Sustainability of Water Resources,
Water Scarcity, Water Quality, Groundwater Use, Allocation of Budget, Planning, Infrastructure Ownership, Information Management.

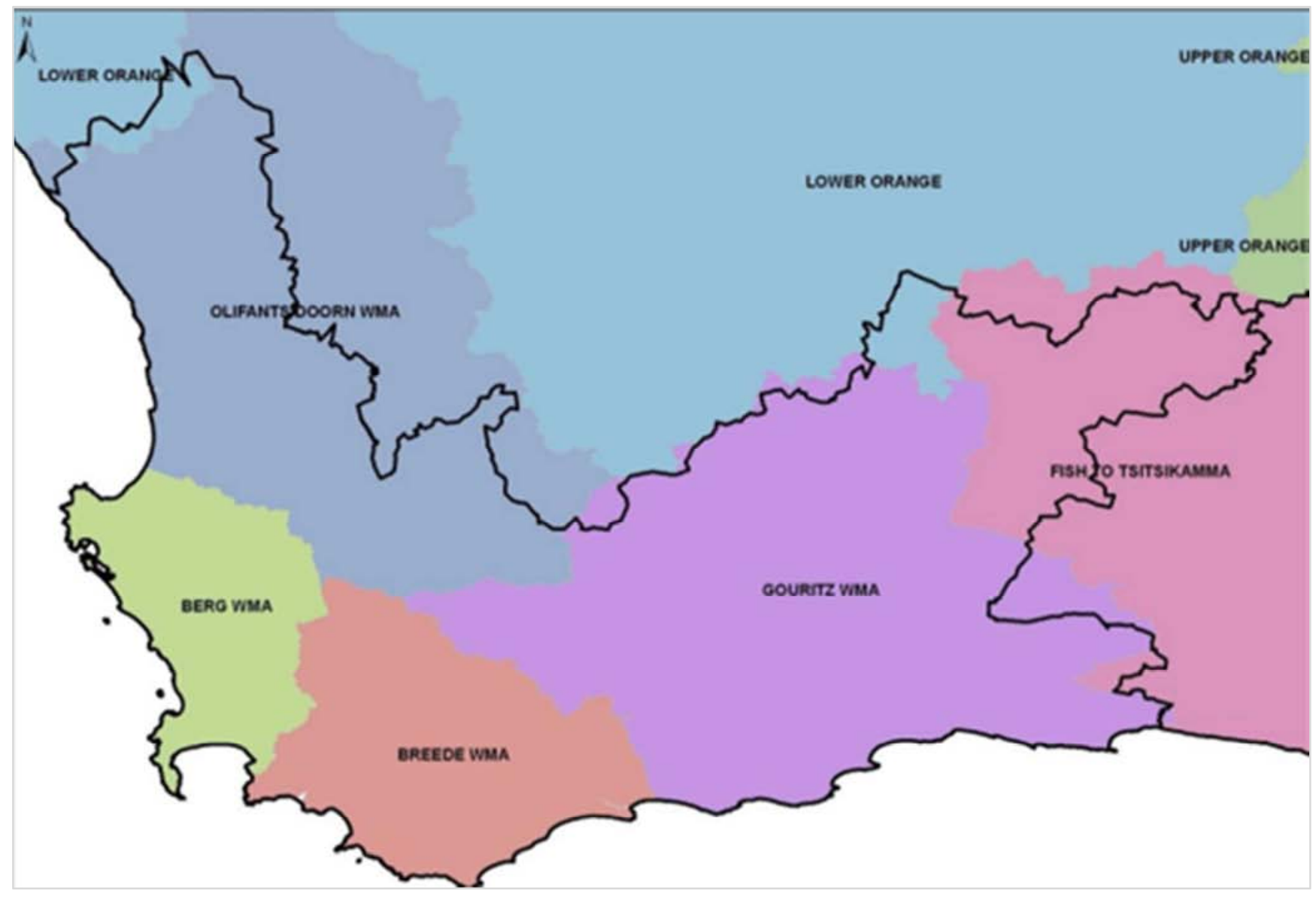

Figure 3. Water Management Areas of the Western Cape [27].

Phase 2: Disaster Restrictions

Disaster Restrictions was to be implemented if and when the total available surface water storage in the Western Cape Water Supply System reaches a point where intensive daily rationing is required to ensure the province has enough water supply to safely reach the next rainfall season or the activation of non-surface water augmentation. Water rationing in this phase was aimed at maintaining human life and critical services (hospitals, schools etc.). Implementation of Phase 2 was to be considered when there was a high likelihood the dam storage will drop below $10 \%$ before the onset of the winter rains. This is significantly different from Preservation Restrictions in that the province will more actively assume control over the daily water supply available to households and businesses.

Phase 3: Full-scale disaster implementation

Full-scale disaster implementation is the extreme disaster scenario which would occur if the Western Cape Water Supply System no longer has surface water supply which the province can access. Non-surface drinking water supplies, sourced from groundwater abstraction from various aquifers and spring water, will be available for drinking purposes only. The province will distribute this water, supplemented by bottled water, to residents through water distribution points. Critical services will be significantly reduced. The province promised the residences that this scenario can be avoided with progressive rationing in Phase 1 and 2 .

\subsection{Day Zero and Public Panic A case of the City of Cape Town}

On "Day Zero", as it is called, the ordinary water supply will be shut down and taps will run dry. Residents of the city of four million will then be forced to collect a daily water ration of just 25-litres from 200 water collection points - not even enough for a two-minute shower in normal times. The city explained that day Zero is calculated by subtracting the expected usage of water from the Western Cape Water Supply System current dam volumes. The method of calculation is not enough to deal with this extremely complex water problem that impacts the lives of the citizens.

\subsubsection{The Days Before Day Zero}

The calculation method ignored a key uncertainty; how the city's population will behave in the weeks and days leading up to Day Zero. A more accurate calculation would take into account exponentially rising water demand as Day Zero 
approaches. It is more likely that as the reality of the taps running dry sets in, the human instincts of self-preservation and panic will begin to take hold and spread across the city's population. This will result in people stockpiling as much water as they can, irrespective of the cost and/or fines, because the consequences of not having supply of water post Day Zero. Thus, it is important that the province either institute broad measures to control water stockpiling, or take the expected escalating demand into consideration when forecasting the Day Zero date.

\subsubsection{The day after Day Zero}

The limited information communicated with the public the day after day zero includes the following:

(a) When the taps go off, residents will have to collect a predefined quantity of drinking water per person per day from approximately 200 sites collection sites across the city that will operate day and night;

(b) Residents will be able to collect 25 litres per person per day to be used for washing, cooking and personal hygiene; day;

(c) Each site is expected to service up to 20000 people per

(d) The province's Water and Sanitation Department will try to limit the impact on sanitation services to limit the risk of disease; and

(e) The South African Police Services (SAPS) and the National Defence Force were consulted to help maintain law and order with law enforcement at collection points.

The communication above was not clear to all citezens and showed an apparent lack of preparedness for the day after Day Zero stems from its shadowy lack of transparency. Such concerns included; the number of water collection sites needs to be at least doubled or tripled to cater for all citezens; parking at the water collection sites, the chaotic queues up kilometres long, and scotching daytime temperatures.

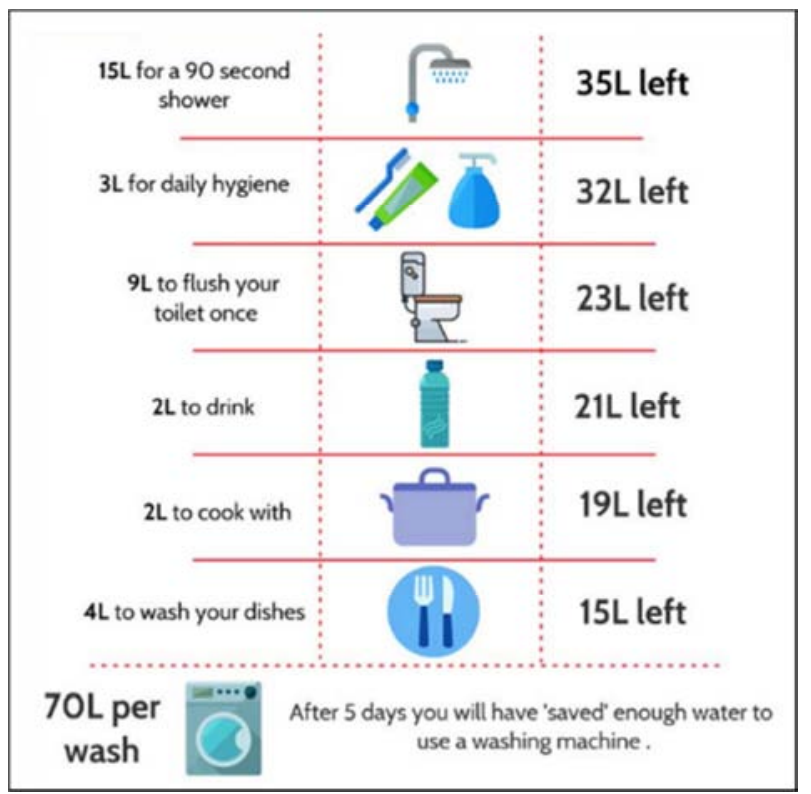

Figure 4. The daily water usage of less than 50 litres per person per day, implemented in Level $6 b$ water restrictions (Graphic: City of Cape Town, 2018).

\section{The Iwrm Pilot Projects Progress and Challenges}

\subsection{Progress}

The Water Plan links with the strategies and planning initiatives of the country and the Western Cape, at National, Provincial and Local Government levels. Below is a summary of the key strategies and planning initiatives reviewed during the development of the Water Plan. The Water Plan has the following 4 strategic goals, which collectively incorporates the 12 themes which were identified in Phase I.

Goal 1

Goal 1ensures effective co-operative governance and institutional planning for sustainable water management. It has three objectives namely: (1) to strengthen and build institutional capacity and integrate institutional structures and mechanisms; (2) adequately allocation of budget in all aspects of sustainable water management and (3) strengthen integration between sustainable water management, ecological sustainability and planning processes, and integrate these with water allocation reform and water reconciliation strategies.

Goal 2

Goal 2 ensures the sustainability of water resources for growth and development. It has three objectives namely: (1) to develop, promote and implement effective and efficient water conservation and water demand management; (2) to promote the sustainable use of groundwater and (3) to effectively monitor, evaluate and report water conservation and water demand management

Goal 3

Goal 3 ensures the integrity and sustainability of socioecological systems. It has three objectives namely: (1) strengthening the monitoring and enforcement of compliance to water quality objectives; (2) to ensure that ecological sustainability is maintained and (3) to effectively implement monitoring programmes to report on the status of water quality objectives.

Goal 4

Goal 4 ensures effective and appropriate information management, reporting and awareness-raising of sustainable water management. It has two objectives namely: (1)to raise awareness of sustainable water management and ecological systems and (2) to effectively and integrate management and reporting of water information.

\subsection{Challenges}

It can be argued by many authors that IWRM might be considered as the means to resolve complex environmental problems caused by anthropogenic sources. In South Africa and other developing countries, the implementation of water resource management has shifted over the years into a more cooperative governance framework. This framework promotes local level management of resources which requires both financial resources and capacity at a local level. Ensuring 
stakeholder willingness requires that both government and civil society understand the necessity surrounding water resource management, however the skills shortage in both local and national departments may impact on its ability to effectively monitor the local level situation. The programmes developed for capacity building at a government level and awareness training at a local level will promote water resource management from a bottom up approach.

The greatest challenge is the minimal skills and capacity of water sector practitioners (engineers, technicians and scientists) as well as the Civil Society Organizations operating in the sector. This challenge also poses a threat to sustainability of services which have to be ensured by among other things proper constant maintenance and operations systems of completed schemes.

Climate change continues to have the potential to impact in the Western Cape and South Africa's water resources significantly and long-term planning and water management decisions must incorporate both the current water demands whilst still implementing strategies to minimise the impacts of climate change on future water resources. Seeking environmentally acceptable and cost efficient water supply technologies remains a challenge to South Africa. The Western Cape has currently developed alternative resource supplementation for consideration in the future (such as desalination and groundwater).

\subsection{Implications of Iwrm Practice for Water Resource Management in the Western Cape}

A critical question is - what does the above analysis imply in terms of the challenges facing the application and implementation of IWRM in the Western Cape?

First, there are internal and external factors that led to water sector reforms in South Africa. The internal factors include water scarcity in terms of quantity (seasonal, geographical and especially in relation to agriculture; floods and droughts in recent years) and quality; the conflicts between the new users in the context of population growth and urbanisation. This called for IWRM in the province. The external factors include the fact that the government, supported by influential political organisations, and not by the water resource stakeholders themselves, initiated IWRM and to that extent represents ideologies and principles imported from groups not trained professionally for water resource management. These approaches did not take into account the nature of the social and economic problems; and the available resources in the province and country; or existing stakeholder perceptions; and the prolonged climate predictions from both the South African Weather Services (SAWS) and Water Research Commission (WRC). This resulted in a discrepancy between the scientific research outputs from water resource related issues and the decision makers, thus impacting the relevance and ownership of and commitment to the concept of IWRM.

Challenges to IWRM and good water governance should allow all stakeholders to participate directly in all aspects of policy making. Significant connections exist between the elements of social capital and the perceptions of stakeholders towards water allocation policies.

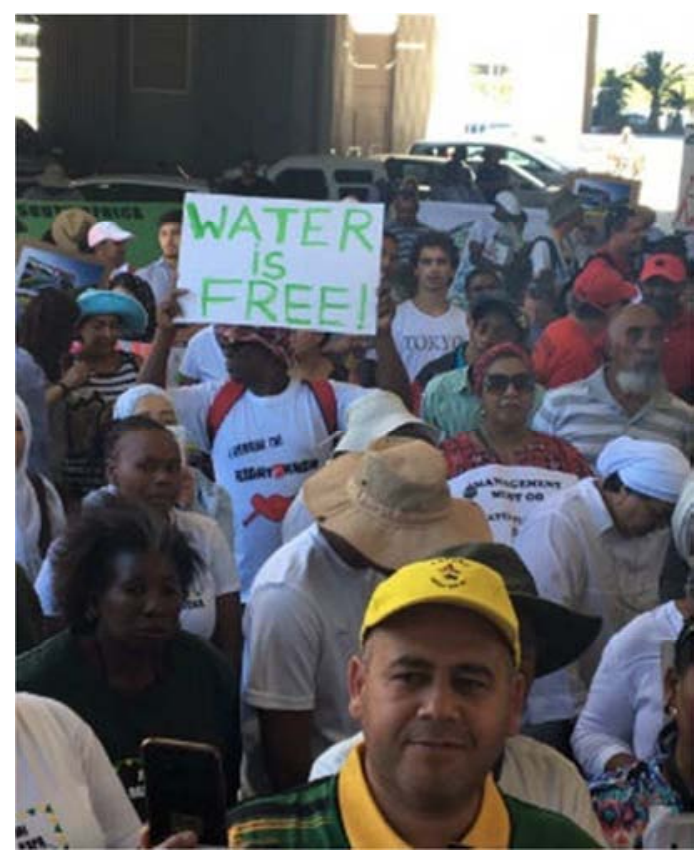

Figure 5. Scenes from a water protest in Cape Town.

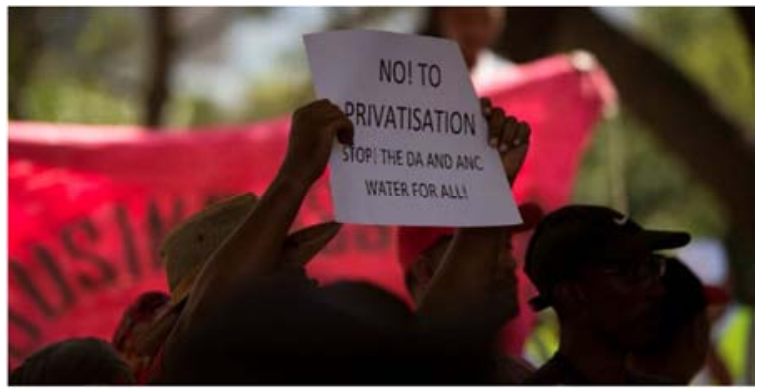

Figure 6. People protesting against major political parties (Democratic Alliance, DA and the African National Congress) asking them to refrain from water issues (Source: [18]).

\section{Conclusions}

This paper presented a brief review on water availability and water-related issues in the Western Cape and reveals challenges of the future IWRM to support sustainable development. Taken together, the key challenges identified in the management of water resources are climate change, and increasing water demand due to population growth and agricultural production. The most apparent measure toward resolving the present problems and constraints of implementing the IWRM approach is by means of good water governance, transparency and full stakeholder involvements, which first of all must start with massive campaigning programs to develop the public's sense of belonging, so that the communities as a whole are willing to participate in IWRM practices. Capacity buildings of enabling environment, institutional frameworks and management instruments were highlighted to contribute towards implementation of the future Iwrm. 


\section{Acknowledgements}

The authors would like to acknowledge financial support from the Cape Peninsula University of Technology, University Research Fund: Research Project: R588 and the Environmental Management Masters Class of 2017.

\section{References}

[1] Agyenim, J. B. and Gupta, J. 2012. "IWRM and developing countries: Implementation challenges in Ghana." Physics and Chemistry of the Earth 47-48: 46-57.

[2] Cape Argus. "Western Cape Weather" Cape Argus, 2017.

[3] Cape Argus. "Western Cape Weather" Cape Argus, 2018.

[4] Chamier, J., Schachtschneider, K., Le Maitre, D. C., Ashton, P. J. and Van Wilgen, B. W., "Impacts of invasive alien plants on water quality, with particular emphasis on South Africa." Water SA 38 (2): 345-356.

[5] Colvin, C. and Saayman. I. 2007. "Challenges to groundwater governance: A case study of groundwater governance in Cape Town, South Africa." Water Policy 9: 127-148.

[6] Conca, K. 2006. "Governing water, contentions transnational politics and global institution building." International Environmental Agreements, Cambridge, Mass: MIT Press. Governing Board.

[7] Crane, W. and Swilling, M. 2008. "Environment, Sustainable Resource Use and the Cape Town Functional Region - An Overview." Urban Forum, 19, (3): 263-287.

[8] Department of Water Affairs and Forestry. 1998. Guide to the National Water Act, Accessed 09 November 2017, http://www.dwaf.gov.za/Documents/Publications/NWAguide.pdf

[9] Department of Water Affairs and Forestry. 2004. National Water Resource Strategy: Our Blue print for survival." 1st Edition ed, Accessed 06 October 2017 http://www.wrc.org.za/Knowledge\%20Hub\%20Documents/Ot her/NWRA\%20Sept04.pdf

[10] Department of Water Affairs. 2012. "Proposed National Water Resources Strategy 2 (NWRS 2): Summary." Accessed 11 November 2017, https://cer.org.za/wpcontent/uploads/2017/10/Draft-NWRS2.pdf

[11] Department of Water Affairs. 2013. "Annual national state of water report for the hydrological year 2012/2013." Accessed $10 \quad$ November 2017, http://www.dwa.gov.za/Groundwater/documents/Annual\%20 National\%20State\%20Water\%20Report\%20for\%20Hydrologi cal\%20Year\%202012-13_Final.pdf.

[12] Enright, W. D. 2000. "The effect of terrestrial invasive alien plants on water scarcity in South Africa." Physics and Chemistry of the Earth, Part B: Hydrology, Oceans and Atmosphere, 25 (3): 237-242.

[13] Figueres, C. M., Tortajada, C. and Rockstrom, J, 2003. "Rethinking water management: innovative approaches to contemporary issues." Earths can Publications Ltd, London.

[14] Hooper, B. 2005. "Integrated river basin governance. learning from international experience." International Water Association Publishing, London.
[15] MacKellar., N., New, M. and Jack, C. 2014. "Observed and modelled trends in rainfall and temperature for South Africa: 1960-2010.” South African Journal of Science 110 (7-8): 1-13.

[16] Mukheibir, P. and Ziervogel, G. 2007. "Developing a Municipal Adaptation Plan (MAP) for climate change: the city of Cape Town." Environment and Urbanization 19 (1): 143158.

[17] Mukheibir, P. 2010. "Water access, water scarcity, and climate change.” Environmental management 45 (5): 1027-1039.

[18] News 24. 2018. "Panic and blame as Cape Town braces for water shut-off" Available athttps://www.news24.com/SouthAfrica/News/panic-andblame-as-cape-town-braces-for-water-shut-off-20180128.

[19] Pahl-Wostl, C. 2007. "Transition towards adaptive management of water facing climate and global change." Water Resources Management 21, 49-62.

[20] Pollard, S. and du Toit, D. 2008. "Integrated Water Resources Management in a Complex System.” Water SA 6, (34): 671680.

[21] Tewari, D. D. 2009. "A detailed analysis of evolution of water rights in South Africa: An account of three and a half centuries from 1652 AD to present." Water SA 35 (5): 693-710.

[22] Thomas, C. D., Cameron, A., Green, R. E., Bakkenes, M., Beaumont, L. J., Collingham, Y. C., Erasmus, B. F., De Siqueira, M. F., Grainger, A., Hannah, L. and Hughes, L. 2004. "Extinction risk from climate change." Nature, 427 (6970): 145-148.

[23] United Nations General Assembley, 2015, United Nations Summit on Sustainable Development 2015, 25-27 September 2015, United Nations Headquarters, New York.

[24] Uys, M. 2008. "Water law of South Africa 1912-1998, Water Research Commission." Accessed 03 January 2018, http://www.wrc.org.za/Knowledge\%20Hub\%20Documents/R esearch\%20Reports/KV203-WATER\%20LAW.pdf.

[25] Western Cape Government. 2011. "Integrated Water Resources Management Action Plan." Accessed 15 October 2017

https://www.westerncape.gov.za/other/2011/8/final_draft_exec _summary_report_2011.pdf

[26] Western Cape Government. 2012 (a). "Municipal governance reports for the period ended June 2012, Accessed 10 October 2017, https://www.westerncape.gov.za/text/2012/11/city-ofcape-town-rmt.pdf

[27] Western Cape Government. 2012 (b). "Western Cape Sustainable Water Management Plan: Part 1: "The Water Plan.” Accessed January 03 2018, https://www.greencape.co.za/assets/Water-Sector-DeskContent/WC-DEAP-DWS-Western-Cape-sustainable-watermanagement-plan-2012.pdf.

[28] Wilson, J. 2011. "Water and climate change: an exploration for the concerned and curious." Environmental Monitoring Group, Cape Town, South Africa.

[29] Ziervogel, G., Shale, M. and Du, M. 2010. "Climate change adaptation in a developing country context: The case of urban water supply in Cape Town." Climate and Development 2 (2): 94-110. 